\title{
РЕЛИГИЈСКИ КОРЕНИ ЕКВИВАЛЕНТНОСТИ ПРИРОДНИХ И ДРУШТВЕНИХ ЗАКОНИТОСТИ
}

\author{
Драган М. Марковић* \\ Висока школа - Академија СПЦ за уметности \\ и консервацију, Београд \\ Ивана Д. Марковић** \\ Worldwide Clinical Trials, Београд \\ Драгана Д. Марковић*** \\ Worldwide Clinical Trials, Београд
}

Сажетак: Проучавањем физичкохемијских законитости и појава које су комплементарне са физичким и хемијским, могу се уочити юихове аналогије са неким појавама у друштву. Анализирајући појаву влаге у зидовима неминовно је срести се са капиларном влагом.

Капиларност је повезана са течностима које квасе зидове суда и уколоко се налазе у капиларним цевчицама пењу се уз њихове зидове насупрот сили земљине теже. Да ли течност кваси зидове суда или не условљено је односом кохезионих сила унутар течности и адхезионих сила између молекула течности и зидова суда.

Висина (h) до које се течнос пење у капилари директно је сразмерна површинском напону течности ( $\gamma)$ а обрнуто сразмерна густини течности ( $\rho$ ), убрзању силе земљине теже (g) и полупречнику капиларе (r). Узајамни односи међумолекулских интеракиија кохезионих и адхезионих сила се аналогно могу пресликати на друштвене појаве, раскола, раслојавања и распадања друштвене заједнице, организачије и породице.

\footnotetext{
*ел.пошта: rabrovica@gmail.com

**ел.пошта: ivana.markovic@worldwide.com

*** ел.пошта: dragana.markovic@worldwide.com
} 
Капиларност је послужила као иницијална природна законитост и појава чија суштина лежи у односима интензитета кохезионих и адхезионих сила. Њихов карактер је послужио као основа за аналогно упоређење са друштвеним односима и појавама. Трагањем за коренима свих законитости и појава неизоставно је почети од Светог Писма као најдрагоиенијег и најпоузанијег извора.

Кључне речи: капиларност, кохезионе силе, адхезионе силе, раскол, раслојавање, распадање, друштво, породииа.

\section{1. Теоријске основе капиларности}

Понашање течности на граници додира чврсте и течне фазе зависи од две врсте сила. Сила узајамног дејства молекула течности и сила молекула течности и зидова чврсте фазе. Кохезионе силе су привлачне силе између молекула исте врсте, док су адхезионе силе привлачне силе између молекула различитих врста. Међусобна интеракција ових сила се може разматрати преко угла квашења (додира) $\theta$.

На слици 1.1. приказани су углови квашења (угао између зида суда у ком се налази течност и тангенте на површину течности) течности која кваси зидове суда (а) и течности која не кваси зидове суда (б). ${ }^{1}$

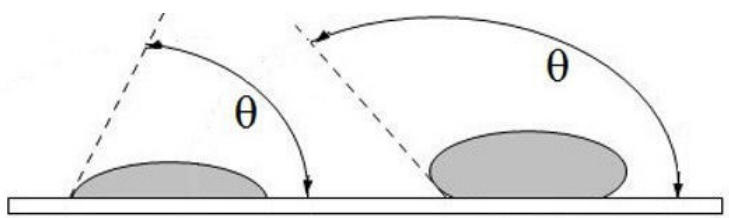

a)

б)

Слика 1.1. а) угао квашења течности која кваси зидове суда $\theta<90^{\circ}$

б) угао квашења течности која не кваси зидове суда $\theta>90^{\circ}$

1 Драган М. Марковић, Физичка хемија (Београд: Академија Српске Православне Цркве за уметност и консервацију 2008). 
Угао квашења директно зависи од односа кохезионих и адхезионих сила. Када су адхезионе силе јаче од кохезионих сила угао квашења је мањи од $90^{\circ}\left(\theta<90^{\circ}\right)$ и за ту течнос кажемо да кваси зидове суда (капљица воде на стакленој подлози). У супротном случају кад су адхезионих сила слабије од кохезионих сила угао квашења је већи од $90^{\circ}\left(\theta>90^{\circ}\right)$ и за ту течност кажемо да не кваси зидове суда (капљица $H g$ на стакленој подлози). Смањење угла квашења се испољава тежњом ка разливањем капи која је директна последица слабљења кохезиони сила и јачањм адхезионих сила.

Појава подизања и спуштања нивоа течности у капиларним цевчицама (пречника мањих од $1 \mathrm{~mm}$ ) се назива капиларност.

Капиларно подизање течности ( слика 1.2.a) је могуће само уколико дата течност кваси зидове суда у супротном случају када течност не кваси зидове суда долази до капиларног спуштања течности ( слика 1.2.б).

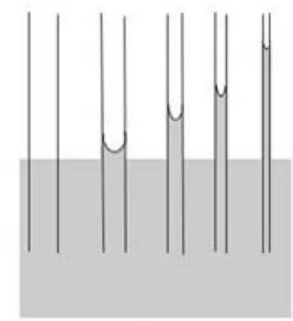

a)

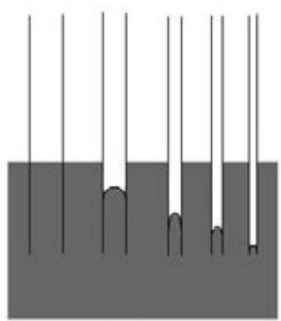

6)

Слика 1.2. Потапања (вертикалана) једне шире цеви и капилара све мањих унутрашњих

На слици 1.2. приказано је потапање (вертикално) шире стаклене цеви и неколико цеви чији се унутрашњи пречници смањују (капиларе), а које су потопљене у течност која кваси зидове суда (а) тј. води и течност која не кваси зидове суда (б) нпр. $\mathrm{Hg}$.

Са слике 1.2. је јасно уочава да потапање широке цеви било у воду или $H g$ нема утицаја на висину њиховог нивоа у цеви. 
Смањујући унутрашњи пречник цеви јасно се уочава да ниво течности која кваси зидове суда у њима расте (а), док у цевима које су потапане у течност која не кваси зидове суда ниво течности у њима се смањује (б).

Овакво подизање или спуштање нивоа течности у узаним цевима (капиларама) назива се капиларност. Капиларност je могуће објаснити чињеницом, да услед закривљености површине течности долази до промене притиска на унутрашње зидове капилара. ${ }^{2}$

Да би се течност густине $\rho$ која кваси зидове суда капиларно подигла на висину $h$ укупна сила површинског напона $F n н$ која делује дуж целог мениска капиларе $2 \pi r$ и износи $F n н=2 \pi r \gamma$, где је $\gamma$ коефицијент површинког мапона, мора да се изједначи са силом Земљине теже $F 3 m=m g$ која делује насупрот силе површинског напона,

$$
\begin{gathered}
F_{\Pi \mathrm{H}}=F_{3 \mathrm{~T}} \\
2 \pi r \gamma=m g
\end{gathered}
$$

Како је маса течности $m=\rho V$ а запремина $V=r^{2} \pi h$, тежина стуба висине $h$ у капилари ће износити $\rho r^{2} \pi h g$. Заменом ових вредности у једначину 1.2. добијамо

$$
2 \pi r \gamma=\rho r^{2} \pi h g
$$

одакле је

$$
h=2 \gamma / \rho g r
$$$$
1.4
$$

\section{2. Дискусија}

Анализом једначине 1.4. јасно се може уочити да ће висина стуба течности $h$ која кваси зидове суда бити утолико већа уколико је већа вреност коефицијента површинског напона течности $\gamma$, мања густина течности $\rho$ и мањи полупречник капиларе $r$. Капиларност је природна појава.

Уколико дејства „унутрашњих“ кохезионих привлачних међумолекулских сила које владају у течностима које

2 Драган М. Марковић, Одабрана поглавља физичке хемије (Београд: Факултет за примењену екологију, Универзитет Сингидунум, 2013). 
квасе зидове суда условно поистоветимо са интензитетом заједништва, јединства религијских, друштвених међуљудских и породичних односа а интензитете „спољашњих“ адхезионих привлачних сила које делују између молекула на површини течности и површине зидова суда то јест на граници њихових додира и које делују насупрот кохезионих сила, условно поистоветимо са деструктивним дејством на заједништво, јединство религијских, друштвених међуљудских и породичних односа, могуће је на основу анализа њихових интензитета предвидети и сагледати њихове последице. ${ }^{34}$

Раскол, раслојавање и распадање друштене целине, породице није могућу случају кадајеинтензитет „унутрашњих“ кохезионих сила већи од интензитета "спољашњих“ граничних адхезионих сила. Доминацијом интензитета адхезионих „спољашњих“ граничних сила над ,унутрашњим“ кохезионим силама узрокује раскол, раслојавање, цепање односа у друштвеним заједницама и породицама.

Уколико су елементи, чланови и делови посматране целине међусобно у интензивнијем сагласју, „љубави“ утолико је и њихова компактност, целовитост и недењивост израженија. Свето јеванђеље по Матеју (МТ 22, 39,) : „љуби ближњега својега као самог себе“. Љубећи ближњег свог као самог себе учвршћује се и јача компактност у религији, друштву, породици и природи чиме се огледа њихова еквивалентност. ${ }^{5}$

\section{Закључак}

У Светом јеванђељу (Мт 22, 39): „љуби ближњега својега као самог себе“ јасно се поручује да испољена љубав ка ближњем свом по интензитету буде једнака љубави према самом себи. Поштујући и испољавајући ову равнотежу љубави неминовно и непогршиво нас води ка збижавању и

\footnotetext{
${ }^{3}$ Драган М. Марковић и Ивана Милошевић, „Утицај унутрашње микроклиме озона и аеросола у црквама на културно наслеђе”, Живопис 6, 2012: 123-138. 4 Драган М. Марковић, „Видљиво и невидљиво”, Живопис 7, 2013: 311-348. ${ }^{5}$ Библија - Свето Писмо Старог и Новог Завета (Београд: Библијско друштво СЦГ, 2004).
} 
учвршћивању унуташњих повезаности и јачању „кохезионог јединства“. Што искреније и интезивније ,љубимо“ ближње свога јачамо компактност целине, наше религије, цркве, друштва, породице и њихова целовитост бива отпорнија на „спољашње“ дестуктивне силе утицаја чији је циљ да их надвладају и разоре. Доминацијом интензитета ,унутрашњих“ сила наспрам „спољашњих“ целовитост остаје сачувана. Нема раскола у Цркви, раслојавања и цепање односа у друштву и породици.

Суштински се ту може уочити аналогнија са законима и појавама у природи и на тај начин се испољава њихова међусобна еквивалентност. Природа и човек су дати од Бога, тако да и међу њиховим законитостима мора постојати еквивалентност и сагласје. Суштина и корени свих законитости саткане су у Светом Писму. Свето Писмо је најдрагоценији егзактни извор.

\section{Литература:}

Марковић, Драган М. Физичка хемија. Београд: Академија Српске Православне Цркве за етност и консервацију, 2008.

Марковић, Драган М. Одабрана поглавља физичке хемије. Београд: Факултет за примењену екологију; Универзитет Сингидунум, 2013.

Марковић, Драган М. и Ивана Милошевић. „Утицај унутрашње микроклиме озона и аеросола у црквама на културно наслеђе”. Живопис 6, 2012: 123-138.

Марковић, Драган М. „Видљиво и невидљиво”, Живопис 7, 2013: 311-348.

Библија - Свето Писмо Старог и Новог Завета (Београд: Библијско друштво СЦГ, 2004). 


\title{
RELIGIOUS ROOTS OF EQUIVALENCE OF NATURAL PHENOMENA AND SOCIAL LAWS
}

\author{
Dragan M. Marković \\ Academy of the Serbian Orthodox Church for Arts and \\ Conservation, Belgrade \\ e-mail: rabrovica@gmail.com \\ Ivana D. Marković \\ Worldwide Clinical Trials, Београд \\ e-mail: ivana.markovic@worldwide.com \\ Dragana D. Marković \\ Worldwide Clinical Trials, Београд \\ e-mail: dragana.markovic@worldwide.com
}

Summary: Religious roots of equivalence of natural phenomena and social lawsPart of abstractResearching of physicochemical laws and phenomena, their analogy with phenomenon in societycan be noticed. Analyzing moisture in walls it is inevitably to meet capillary moisture.Capillarity - initial natural law and phenomena, as well as her character serve as base for analogcomparison with social relations and occurrence. Searching for roots of all laws and phenomenamust be started with Holy Bible as most valuable and most reliable source.

Keywords: capillarity, cohesion forces, adhesion forces, split, stratification, decay, society, family. 